\title{
Noninvasive Ventilation and High-Flow Nasal Cannulae Therapy for Children with Acute Respiratory Failure An overview
}

"Khaloud S. Al-Mukhaini and Najwa M. Al-Rahbi

$$
\begin{aligned}
& \text { التهوية غير الباضعة وعلاج قنيات الأنف ذات التدفق العالي } \\
& \text { لأكُطفال المصابين بالفشل التنغسي الحاد } \\
& \text { استعراض عام }
\end{aligned}
$$

خلود سعيد المخينية و نجوى مرهون الرحبية

\begin{abstract}
Noninvasive ventilation (NIV) refers to the use of techniques to deliver artificial respiration to the lungs without the need for endotracheal intubation. As NIV has proven beneficial in comparison to invasive mechanical ventilation, it has become the optimal modality for initial respiratory support among children in respiratory distress. High-flow nasal cannulae (HFNC) therapy is a relatively new NIV modality and is used for similar indications. This review discusses the usefulness and applications of conventional NIV in comparison to HFNC.
\end{abstract}

Keywords: Noninvasive Ventilation; Nasal Cannulae; Endotracheal Intubation; Mechanical Ventilation; Children.

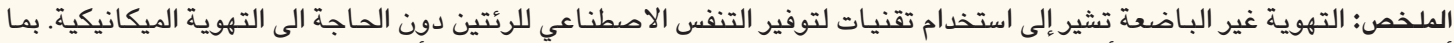

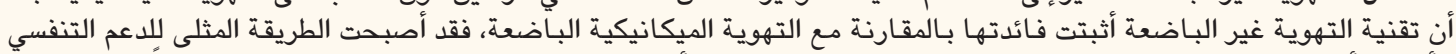

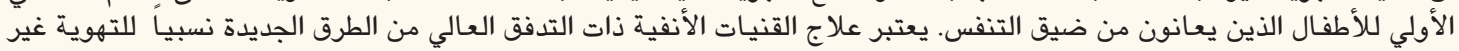

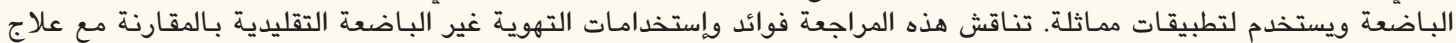
القنيات الأنفية ذات التدفق العالي.

الكلمات المفتاحية: التهوية غير الباضعة؛ قنيات أنفية؛ تنبيب الرغامى؛ التهوية الميكانيكية؛ الأطفال.

1 He use of noninvasive deVices in The treatment of acute respiratory distress has increased in paediatric care over the last decade. ${ }^{1}$ Noninvasive ventilation (NIV) includes the use of an interface to support breathing, thus avoiding invasive procedures like endotracheal intubation. ${ }^{2}$ Techniques for NIV include continuous positive airway pressure (CPAP), bilevel positive airway pressure (BPAP) and, more recently, high-flow nasal cannulae (HFNC). ${ }^{1,3}$ This article discusses conventional NIV in comparison with HFNC therapy.

\section{Conventional Noninvasive Ventilation}

Various adult and paediatric studies have demonstrated the advantages of conventional NIV modalities, such as reducing the need for invasive mechanical ventilation and, therefore, its associated complications. ${ }^{2,4-6}$ In an adult randomised controlled trial (RCT), Antonelli et al. found that NIV resulted in a reduced risk of pneumonia and sinusitis; moreover, pulmonary gas exchange resulted in similar effects to invasive mechanical ventilation within the first hour of treatment. ${ }^{2}$ Yañez et al. reported similar findings among 50 children with respiratory failure, in which the NIV group demonstrated significant improvement following gas exchange within the first hour as well as a reduced need for intubation. ${ }^{4}$ In other studies, NIV use has reduced the length of intensive care unit (ICU) stay. ${ }^{5,6}$ Furthermore, NIV has economic advantages over conventional mechanical ventilation, as most children undergoing invasive mechanical ventilation require ICU admission and additional interventions, thereby increasing the overall cost of treatment.?

Over time, NIV has become the first line of treatment for paediatric respiratory distress in many countries. ${ }^{1,5,8}$ Moreover, in view of the advantages of this modality, its 
use has been adopted not only in specialised paediatric ICUs but also in general emergency departments, transport teams and general wards, although trained staff and proper equipment are still necessary. ${ }^{9}$

\section{MECHANISM OF ACTION}

CPAP involves the use of continuous distending pressure applied to the airway at a constant level. ${ }^{10,11}$ On the other hand, BPAP delivers two different types of pressure during inspiration and expiration, respectively. ${ }^{11}$ Both CPAP and expiratory positive airway pressure during BPAP allow for the relief of upper airway obstruction and lung recruitment resulting in enhanced gas exchange, thereby reducing ventilation-perfusion mismatching and improving oxygenation and carbon dioxide $\left(\mathrm{CO}_{2}\right)$ clearance. ${ }^{10,11}$ In addition, BPAP devices have the option of a backup rate to ensure a minimum respiratory rate is maintained in cases where respiratory effort is inadequate.

Essouri et al. reported the physiological effects of NIV in children presenting with acute respiratory failure; the study showed that children receiving NIV had significantly improved work of breathing (WOB) as well as blood gas results and inspiratory muscle effort. ${ }^{12}$ Additionally, oesophageal and diaphragmatic pressure-time products dropped with NIV treatment, while measured tidal volume and minute ventilation increased..$^{12}$

\section{CLINICAL INDICATIONS AND APPLICATIONS}

For infants and children presenting with acute respiratory distress and secondary respiratory failure, NIV is the first line of treatment to improve gas exchange, avoid invasive ventilation and prevent extubation failure. Ganu et al. reported an annual 2.8\% increase in NIV use among bronchiolitis patients over a nine-year period, with an annual $1.9 \%$ drop in the rate of invasive ventilation. ${ }^{5}$ Both Wolfler et al. and Essouri et al. have reported similar declines in the rate of invasive mechanical ventilation corresponding to an increase in NIV use. .,13 $^{8}$

Different success rates with NIV use have been reported for various clinical diseases. Essouri et al. and Abadesso et al. reported overall success rates of $77 \%$ and $77.5 \%$, respectively, among paediatric patients receiving NIV for different causes of respiratory distress. $^{13,14}$ However, children admitted with acute respiratory distress syndrome (ARDS) has less favourable outcomes compared to those admitted with pneumonia, sickle cell disease presenting with acute chest syndrome and immunocompromised patients presenting with acute respiratory failure. ${ }^{13}$ In two other studies of infants treated for bronchiolitis, the NIV success rate was $81-83 \%{ }^{5,15}$ Children with asthma also reportedly respond well to NIV treatment, with improvements in WOB and asthma severity scores. ${ }^{16}$
In addition, NIV is also indicated in the prevention of postextubation respiratory failure, either prophylactically for children at high risk of extubation failure or to treat those with postextubation respiratory distress or failure. In a recent study, the NIV success rate was higher when utilised prophylactically in comparison to its use as a rescue treatment. ${ }^{17}$ In addition, NIV resulted in an overall success rate of $85 \%$ in the postextubation period among children receiving treatment after open heart surgery. ${ }^{18}$ Children with underlying malignancies who present with acute respiratory failure are also candidates for NIV. However, careful patient selection is required as therapy usually fails for cases with a more severe clinical course, significant pulmonary disease or haemodynamic instability. ${ }^{19}$ The NIV success rate among children with ARDS and substantial acute lung injuries is between $30-50 \%{ }^{20}$ Therefore, it is highly advised that children with ARDS are closely monitored when NIV is initiated so that any deterioration in their respiratory state can be immediately addressed. Furthermore, NIV is recommended early during the ARDS disease process in order to avoid muscle fatigue from the increase in WOB and to improve gas exchange. ${ }^{20}$ Table 1 provides a summary of selected studies investigating NIV use in children., ${ }^{4,814,19}$

\section{INTERFACE CHOICE}

A wide range of interfaces are available for NIV therapy, including helmets, full-face masks, oronasal masks, nasal masks and nasal cannulae. For children, the choice of interface plays an important role in affecting their NIV tolerance. In general, most interfaces are effective in reducing WOB and improving gas exchange. ${ }^{21}$ An ideal NIV interface is one that is comfortable, does not cause claustrophobia, has minimal leakage and results in the least patient-ventilator asynchrony. Nasal masks are generally better tolerated and have less dead space than other types of interfaces. In addition, children are often better able to communicate and thus more comfortable. However, the use of nasal masks is limited in children due to air leaking through the mouth. ${ }^{22,23}$ In contrast, full-face or oronasal masks result in minimal leakage and ventilator patient asynchrony, although patients can experience intolerance and discomfort. ${ }^{24}$ Differences in leakage, side-effects and asynchrony with different NIV interfaces are not well described in the literature. The British Thoracic Society recommends having different sizes and types of NIV interfaces available to ensure treatment success. ${ }^{25}$

\section{MONITORING AND PREDICTING RESPONDERS}

Although NIV use is primarily advised for children with respiratory distress, it is also recommended to differ- 
Table 1: Summary of selected studies evaluating the use of noninvasive ventilation in children ${ }^{4,8,14,19}$

\begin{tabular}{|c|c|c|c|c|}
\hline $\begin{array}{l}\text { Author and } \\
\text { year of study }\end{array}$ & $\begin{array}{l}\text { Study design and } \\
\text { period }\end{array}$ & $\begin{array}{l}\text { Mode of } \\
\text { NIV }\end{array}$ & Patients & Clinical results \\
\hline $\begin{array}{l}\text { Yañez et al. } \\
(2008)\end{array}$ & $\begin{array}{l}\text { Prospective RCT } \\
(2005)\end{array}$ & BPAP & $\begin{array}{l}50 \text { children admitted to } \\
\text { the PICU with respiratory } \\
\text { distress }\end{array}$ & $\begin{array}{l}\text { - The rate of intubation in the NIV } \\
\text { group was } 28 \% \text { compared to } 60 \% \text { in } \\
\text { the control group }\end{array}$ \\
\hline $\begin{array}{l}\text { Wolfler et al. } \\
\text { (2015) }\end{array}$ & $\begin{array}{l}\text { National } \\
\text { multicentre } \\
\text { observational } \\
\text { retrospective study } \\
(2011-2012)\end{array}$ & $\begin{array}{l}\text { CPAP and } \\
\text { BPAP }\end{array}$ & $\begin{array}{l}\text { 7,100 children admitted to } \\
\text { the PICU with respiratory } \\
\text { failure }\end{array}$ & $\begin{array}{l}\text { The use of NIV increased from } \\
11.6 \% \text { in } 2006 \text { to } 14.3 \% \text { in } 2011 \text { and } \\
18.2 \% \text { in } 2012\end{array}$ \\
\hline $\begin{array}{l}\text { Abadesso et al. } .^{14} \\
(2012)\end{array}$ & $\begin{array}{l}\text { Observational } \\
\text { prospective study } \\
(2006-2010)\end{array}$ & $\begin{array}{l}\text { CPAP and } \\
\text { BPAP }\end{array}$ & $\begin{array}{c}151 \text { children with respiratory } \\
\text { distress }\end{array}$ & - The overall NIV success rate was $77.5 \%$ \\
\hline $\begin{array}{l}\text { Pancera et al. }{ }^{19} \\
(2008)\end{array}$ & $\begin{array}{l}\text { Observational } \\
\text { retrospective study } \\
(1997-2005)\end{array}$ & BPAP & $\begin{array}{l}239 \text { children admitted to } \\
\text { the PICU with underlying } \\
\text { malignancies and presenting } \\
\text { with respiratory failure }\end{array}$ & $\begin{array}{l}\text { - The overall NIV success rate was } 74 \% \\
\text { - Predictors of NIV failure included } \\
\text { cardiovascular dysfunction and a } \\
\text { TISS of }>40 \text { points }\end{array}$ \\
\hline
\end{tabular}

$N I V=$ noninvasive ventilation; $R C T=$ randomised controlled trial; $B P A P=$ bilevel positive airway pressure; $P I C U=$ paediatric intensive care unit; CPAP = continuous positive airway pressure; TISS = Therapeutic Intervention Scoring System.

entiate those who respond to treatment from non-responders so as to avoid delaying intubation, if necessary, thus worsening patient outcomes..$^{20}$ Specific predictors of NIV failure include worsening vital signs (e.g. respiratory rate and heart rate) following NIV treatment, the presence of isolated respiratory disease versus multiple organ dysfunction and the oxygen saturation $\left(\mathrm{SpO}_{2}\right)$ / fraction of inspired oxygen $\left(\mathrm{FiO}_{2}\right)$ ratio. ${ }^{26-30}$

The $\mathrm{SpO}_{2} / \mathrm{FiO}_{2}$ ratio is used as a clinical indicator for hypoxaemia, with a lower ratio indicating greater severity. ${ }^{26}$ Children with more severe disease upon admission are at increased risk of NIV failure. ${ }^{27}$ Physiological parameters before treatment have also been linked to treatment failure, with responders showing improved respiratory rates, heart rates and blood gas results. ${ }^{28}$ In particular, response to NIV therapy is demonstrated by improved respiratory rates one hour after treatment, with continued improvement in subsequent hours. ${ }^{29}$ Likewise, responders' heart rates have shown improvement 2-6 hours following the intervention. ${ }^{30}$ In contrast, a higher $\mathrm{FiO}_{2}$ requirement and lower $\mathrm{SpO}_{2} / \mathrm{FiO}_{2}$ ratio within one hour of treatment has been associated with treatment failure. ${ }^{26-28,30}$ Finally, children with underlying respiratory disease alone are less likely to fail NIV treatment compared to children with other comorbidities, such as underlying malignancies. ${ }^{27,29}$

\section{High-Flow Nasal Cannulae}

HFNC therapy delivers a humidified oxygen and gas mixture heated to approximately $34^{\circ} \mathrm{C}$, allowing higher air flow rates exceeding $2 \mathrm{~L} /$ minute. ${ }^{3,31,32}$ These features enable the delivery of air flow equal to or greater than the inspiratory flow of a spontaneously breathing patient. ${ }^{31}$
HFNC also has the ability to generate distending pressure. $^{3,31}$ Over the last decade, the use of HFNC has increased among neonates, infants, children and adults for various clinical indications. ${ }^{31-33}$ Long et al. showed that, in a paediatric population presenting with respiratory failure, HFNC had a success rate of $61 \%$ when initiated in the emergency department. ${ }^{34}$

\section{MECHANISM OF ACTION}

HFNC works via different mechanisms to improve oxygenation and ventilation and reduce WOB. Moreover, HFNC reduces nasopharyngeal dead space due to the effect of the high flow on nasopharyngeal oxygen-depleted gas, leading to $\mathrm{CO}_{2}$ clearance. ${ }^{3}$ HFNC improves oxygenation as it provides higher $\mathrm{FiO}_{2}$ compared to conventional oxygen therapy. Additionally, as the gas flow is humidified and warmed, this modality improves lung compliance, reduces airway resistance and aids in secretion clearance. ${ }^{3,31}$

Depending on the patient's weight, the HFNC flow and the size of the nasal cannulae compared to the nares, HFNC is associated with the generation of positive end-expiratory pressure (PEEP). ${ }^{35}$ The amount of generated PEEP is also affected by the degree of leakage via the mouth. ${ }^{35,36}$ An early study of preterm babies suggested that HFNC can generate positive distending pressure similar to that of CPAP and therefore treat apnoea of prematurity. ${ }^{37}$ In a neonate, a flow rate of 3-5 L/minute is equivalent to CPAP at $6 \mathrm{~cm}$ of water $\left(\mathrm{H}_{2} \mathrm{O}\right)$, with effective distending pressure. ${ }^{35,38}$ Moreover, during HFNC, inspiratory pressure remains positive throughout the breathing cycle. Milési et al. measured oesophageal pressures at different flow rates, with a pharyngeal pressure of $0.2 \mathrm{~cm}$ of $\mathrm{H}_{2} \mathrm{O}$ at $1 \mathrm{~L} /$ minute increasing to $4 \mathrm{~cm}$ of $\mathrm{H}_{2} \mathrm{O}$ at 6-7 L/minute. ${ }^{39}$ Overall, 
Table 2: Summary of selected studies evaluating the use of high-flow nasal cannulae in children and adults ${ }^{41,45,49-52}$

\begin{tabular}{|c|c|c|c|}
\hline $\begin{array}{l}\text { Author and year } \\
\text { of study }\end{array}$ & $\begin{array}{l}\text { Study design and } \\
\text { period }\end{array}$ & Patients & Clinical results \\
\hline $\begin{array}{l}\text { Frat et al. }{ }^{41} \\
(2015)\end{array}$ & $\begin{array}{l}\text { Randomised multicentre } \\
\text { open-label trial } \\
(2011-2013)\end{array}$ & $\begin{array}{l}310 \text { adult patients with } \\
\text { acute hypoxaemic } \\
\text { respiratory failure with a } \\
\mathrm{PaO}_{2} / \mathrm{FiO}_{2} \text { ratio of } \\
<300 \mathrm{mmHg}\end{array}$ & $\begin{array}{l}\text { - The rate of intubation in the HFNC group was } \\
38 \% \text { compared to } 50 \% \text { in the NIV group and } 47 \% \\
\text { in the standard oxygen therapy group }\end{array}$ \\
\hline $\begin{array}{l}\text { Hernández et al. }{ }^{49} \\
(2016)\end{array}$ & $\begin{array}{l}\text { Multicentre randomised } \\
\text { clinical trial } \\
(2012-2014)\end{array}$ & $\begin{array}{l}604 \text { critically-ill adult } \\
\text { patients admitted to the } \\
\text { ICU who were at high } \\
\text { risk of extubation with } \\
\text { respiratory failure }\end{array}$ & $\begin{array}{l}\text { - HFNC was not inferior to NIV in preventing } \\
\text { extubation failure and post-extubation respiratory } \\
\text { failure among high-risk patients }\end{array}$ \\
\hline $\begin{array}{l}\text { Pedersen et al. }{ }^{51} \\
(2017)\end{array}$ & $\begin{array}{l}\text { Retrospective study } \\
\quad(2013-2015)\end{array}$ & $\begin{array}{l}49 \text { infants with severe } \\
\text { bronchiolitis }\end{array}$ & $\begin{array}{l}\text { - When compared to HFNC, CPAP was more } \\
\text { effective in reducing respiratory distress } \\
\text { - Overall, } 55 \% \text { of infants being treated with HFNC } \\
\text { had to switch treatment to CPAP }\end{array}$ \\
\hline $\begin{array}{l}\text { Milési et al. }{ }^{52} \\
(2017)\end{array}$ & $\begin{array}{l}\text { Multicentre RCT } \\
\text { (2014-2015) }\end{array}$ & $\begin{array}{l}142 \text { infants admitted to } \\
\text { PICUs with moderate- } \\
\text { to-severe bronchiolitis }\end{array}$ & $\begin{array}{l}\text { - Nasal CPAP is more effective than HFNC in } \\
\text { initial supportive treatment for infants with } \\
\text { moderate-to-severe bronchiolitis }\end{array}$ \\
\hline
\end{tabular}

$\mathrm{PaO}_{2}=$ partial pressure of arterial oxygen; $\mathrm{FiO}_{2}=$ fraction of inspired oxygen; HFNC = high-flow nasal cannulae; NIV = noninvasive ventilation; $R C T=$ randomised controlled trial; $I C U=$ intensive care unit; $C P A P=$ continuous positive airway pressure; PICUs = paediatric intensive care units.

no universal equivalence exists between pressure and flow rate; therefore, close monitoring of the patient remains a necessity.

\section{CLINICAL INDICATIONS AND APPLICATIONS}

The use of HFNC has broad indications, including different causes of respiratory distress. Overall, HFNC is most commonly used among children with bronchiolitis and pneumonia. ${ }^{40}$ Frat et al. found that the use of HFNC in hypoxic respiratory failure reduced the intubation rate to $38 \%$, leading to a greater number of ventilation-free days in an ICU.41 Roca et al. showed that HFNC reduced the need for mechanical ventilation among patients with respiratory failure post-lung transplant. ${ }^{42}$ Kawaguchi et al. conducted a retrospective study evaluating intubation rates in a group of children presenting with respiratory distress. ${ }^{43}$ This study showed reduced intubation rates among children receiving HFNC in comparison to those who did not receive HFNC (38\% versus 63\%), with more ventilator-free days in the former group. However, no differences were observed in terms of mortality rate or paediatric ICU (PICU) length of stay. ${ }^{43}$

In a Cochrane review evaluating the effectiveness of HFNC among children with bronchiolitis, a single pilot study with 19 participants was identified comparing HFNC with oxygen delivery via a headbox; however, there was insufficient evidence to determine the effectiveness of HFNC for treating bronchiolitis. ${ }^{44}$ Nevertheless, a recent multicentre RCT comparing the outcomes of infants with bronchiolitis treated with low-flow oxygen or HFNC showed that there was a reduced need for escalation of care among the group receiving HFNC. ${ }^{45}$ In addition, Schlapbach et al. evaluated the safety of HFNC while transporting ill children between hospitals. ${ }^{46}$ The majority of these children had respiratory conditions requiring admission to a PICU, of which $77 \%$ were diagnosed with bronchiolitis. Overall, the intubation rate decreased from $49 \%$ to $35 \%(P<0.001)$, with none of the HFNC patients requiring intubation, developing pneumothorax or going into cardiac arrest. ${ }^{46}$ Two other studies similarly noted a reduction in intubation rates among infants admitted with bronchiolitis following the introduction of HFNC in PICUs (37\% versus 7\% and 23\% versus $9 \%$, respectively). ${ }^{47,48}$ Various studies investigating HFNC use in children and adults are presented in Table 2 . $^{41,45,49-52}$

In Spain, two RCTs involving seven adult ICUs were conducted to assess the effect of using HFNC in the postextubation period on the incidence of reintubation and respiratory failure in high- and low-risk patients, respectively. ${ }^{49,50}$ In the first trial, high-risk patients who passed spontaneous breathing trials randomly received either HFNC or conventional NIV while, in the second trial, low-risk patients randomly received either HFNC or conventional oxygen therapy. ${ }^{49,50}$ 
No difference was found between the two modalities in terms of preventing reintubation or postextubation respiratory failure among high-risk patients. ${ }^{49}$ However, in low-risk patients, HFNC was superior to conventional oxygen therapy in reducing the risk of reintubation within a 72 -hour period. ${ }^{50}$

\section{ADVANTAGES AND LIMITATIONS}

For infants, HFNC therapy is well tolerated, therefore reducing the need for sedation. Furthermore, the humidified oxygen improves secretion clearance. ${ }^{3}$ Among adults, HFNC minimises mouth dryness and is generally perceived to be more comfortable..$^{53}$ Spentzas et al. assessed the comfort of 46 children with respiratory distress at 60-90 minutes and 8-12 hours following HFNC therapy and found that comfort significantly improved following HFNC use. ${ }^{40}$ Generally, HFNC use has been demonstrated to be safe with few reported complications. In 2005, there was an outbreak of Ralstonia mannitolilytica infections due to contaminated HFNC devices (Vapotherm Inc., Exeter, New Hampshire, USA), which were subsequently withdrawn from the market. ${ }^{54}$ In addition, three cases of serious air leak syndrome have been reported..$^{33}$ Nevertheless, the over-all risk of air leak syndrome with HFNC is no higher than that of low-flow oxygen. ${ }^{45}$

\section{MONITORING AND PREDICTING RESPONDERS}

As with NIV, certain clinical features can predict the response to HFNC therapy. For example, children with improved respiratory distress and heart rates are likely to be responders to HFNC therapy. ${ }^{55}$ Moreover, $\mathrm{FiO}_{2}$ requirements and illness severity are predictors of response to treatment. Accordingly, children with high $\mathrm{SpO}_{2} / \mathrm{FiO}_{2}$ ratios-indicating milder forms of lung injuries - and those with lower respiratory rates are likely to respond to therapy. ${ }^{35}$ Roca et al. conducted a four-year multicentre prospective observational cohort study to assess possible predictors of HFNC failure, in which the respiratory rate oxygenation (ROX) index (i.e. the ratio of pulse oximetry/ $/ \mathrm{FiO}_{2}$ to respiratory rate) was used to assess therapy success. ${ }^{56}$ At a cut-off value of $\geq 4.88$, the ROX index 12 hours after the initiation of HFNC therapy yielded a sensitivity of $70 \%$ and specificity of $72.4 \%$ in predicting successful treatment for patients with pneumonia. ${ }^{56}$

Clinical indicators for HFNC therapy failure include a lack of improvement in oxygenation, thoracoabdominal asynchrony and the presence of haemodynamic and neurological impairment. ${ }^{42,57,58}$ According to Oto et al., a drop in heart or respiratory rate and improvement in the mean dyspnoea score 30 minutes and 12 hours after the initiation of HFNC are indic- ative of successful treatment. ${ }^{55}$ In a cohort of 113 infants with bronchiolitis undergoing HFNC therapy, Abboud et al. observed that a higher Paediatric Risk of Mortality Score-which indicates illness severity upon admission to the ICU-as well as an elevated $\mathrm{CO}_{2}$ level before treatment were predictors of treatment failure. ${ }^{59}$ The study also emphasised that non-improvement in WOB was noted among the non-responders. ${ }^{59}$

\section{Comparison of Therapies}

Early studies have shown that the effectiveness of HFNC is similar to CPAP, with comparable effects on WOB, oxygenation and gas exchange. ${ }^{37,60}$ The advantages of the HFNC system include the easy setup and increase in the child's comfort. ${ }^{34,40}$ In general, HFNC therapy is safe and associated complications, as described earlier, are uncommon. Likewise, NIV treatment is safe, with dry eyes, dry mouth, claustrophobia and pressure effects on the areas of the face covered by the mask being the most common complications. ${ }^{22}$

Recently, several studies have assessed clinical outcomes among children receiving CPAP and HFNC therapy. Pedersen et al. reviewed clinical outcomes among a historical cohort of 49 infants admitted with severe bronchiolitis and treated with CPAP or HFNC. ${ }^{51}$ In both groups, respiratory rate declined with treatment; however, improvements in respiratory distress were faster with CPAP treatment. Moreover, in 55\% of children, the mode of treatment was changed from HFNC to CPAP due to an increase in respiratory distress..$^{51}$ Additionally, a multicentre RCT evaluated the clinical outcomes of infants presenting with moderate-to-severe bronchiolitis, comparing CPAP treatment at a PEEP level of $7 \mathrm{~cm}$ of $\mathrm{H}_{2} \mathrm{O}$ to HFNC therapy at a rate of $2 \mathrm{~L} /$ minute $/ \mathrm{kg} .{ }^{52}$ Only $5.7 \%$ of the infants required intubation, with the rest managed using either HFNC or CPAP. Interestingly, 31\% of the CPAP group failed initial respiratory support compared to $50.7 \%$ of the HFNC group. ${ }^{52}$ The most common reason for failure in the CPAP group was discomfort, while the HFNC group failed due to an increase in respiratory distress. In both groups, there was a crossover of treatment in cases of failure or intolerance to the initial support modality. ${ }^{52}$

An observational study by Pilar et al. investigated the outcomes of children with asthma who were treated with HFNC or NIV. ${ }^{61}$ The study showed no failure in the NIV group, while respiratory support had to be changed to NIV among 40\% of children in the HFNC group, thus showing that CPAP was associated with a more rapid improvement in respiratory distress. ${ }^{61}$ Collectively speaking, while CPAP and HFNC were both associated with improvement in respiratory 
distress, CPAP was superior in treating children with significant respiratory distress. On the other hand, HFNC was associated with improved tolerance in comparison to NIV.52 Therefore, HFNC can be used to treat children presenting with milder or less severe forms of respiratory distress and in cases where patient discomfort is a concern.

\section{Conclusion}

Globally, NIV treatment has become the first line of respiratory support for children and is safe and effective in the treatment of various causes of respiratory distress. However, healthcare practitioners should be aware of the various indicators or predictors of NIV failure in order to avoid unwanted complications associated with delayed invasive ventilation. HFNC therapy is a promising NIV modality of respiratory support and is indicated for milder forms of respiratory distress. Greater use of NIV may reduce the number of referrals to ICUs as well as prevent complications resulting from invasive mechanical ventilation.

\section{References}

1. Ducharme-Crevier L, Essouri S, Emeriaud G. Noninvasive ventilation in pediatric intensive care: From a promising to an established therapy, but for whom, when, why, and how? Pediatr Crit Care Med 2015; 16:481-2. doi: 10.1097/PCC.00000 00000000390 .

2. Antonelli M, Conti G, Rocco M, Bufi M, De Blasi RA, Vivino G, et al. A comparison of noninvasive positive-pressure ventilation and conventional mechanical ventilation in patients with acute respiratory failure. N Engl J Med 1998; 339:429-35. doi: 10.1056/ NEJM199808133390703.

3. Milési $C$, Boubal M, Jacquot A, Baleine J, Durand S, Odena MP, et al. High-flow nasal cannula: Recommendations for daily practice in pediatrics. Ann Intensive Care 2014; 4:29. doi: 10.1186/ s13613-014-0029-5.

4. Yañez LJ, Yunge M, Emilfork M, Lapadula M, Alcántara A, Fernández C, et al. A prospective, randomized, controlled trial of noninvasive ventilation in pediatric acute respiratory failure. Pediatr Crit Care Med 2008; 9:484-9. doi: 10.1097/PCC.0b013 e318184989f.

5. Ganu SS, Gautam A, Wilkins B, Egan J. Increase in use of non-invasive ventilation for infants with severe bronchiolitis is associated with decline in intubation rates over a decade. Intensive Care Med 2012; 38:1177-83. doi: 10.1007/s00134-0 12-2566-4.

6. Keenan SP, Sinuff T, Cook DJ, Hill NS. Does noninvasive positive pressure ventilation improve outcome in acute hypoxemic respiratory failure? A systemic review. Crit Care Med 2004; 32:2516-23. doi: 10.1097/01.CCM.0000148011.51681.E2.

7. Essouri S, Laurent M, Chevret L, Durand P, Ecochard E, Gajdos V, et al. Improved clinical and economic outcomes in severe bronchiolitis with pre-emptive nCPAP ventilator strategy. Intensive Care Med 2014; 40:84-91. doi: 10.1007/s00134-013-3129-z.

8. Wolfler A, Calderini E, Iannella E, Conti G, Biban P, Dolcini A, et al. Evolution of noninvasive mechanical ventilation use: A cohort study among Italian PICUs. Pediatr Crit Care Med 2015; 16:418-27. doi: 10.1097/PCC.0000000000000387.
9. Davies JD, Gentile MA. What does it take to have a successful noninvasive ventilation program? Respir Care 2009; 54:53-61.

10. Morley CJ, Davis PG. Continuous positive airway pressure: Scientific and clinical rationale. Curr Opin Pediatr 2008; 20:119-24. doi: 10.1097/MOP.0b013e3282f63953.

11. Shaffer TH, Alapati D, Greenspan JS, Wolfson MR. Neonatal non-invasive respiratory support: Physiological implications. Pediatr Pulmonol 2012; 47:837-47. doi: 10.1002/ppul.22610.

12. Essouri S, Durand P, Chevret L, Haas V, Perot C, Clement A, et al. Physiological effects of noninvasive positive ventilation during acute moderate hypercapnic respiratory insufficiency in children. Intensive Care Med 2008; 34:2248-55. doi: 10.1007/ s00134-008-1202-9.

13. Essouri S, Chevret L, Durand P, Haas V, Fauroux B, Devictor D. Noninvasive positive pressure ventilation: Five years of experience in a pediatric intensive care unit. Pediatr Crit Care Med 2006; 7:329-34. doi: 10.1097/01.PCC.0000225089.21176.0B.

14. Abadesso C, Nunes P, Silvestre C, Matias E, Loureiro H, Almeida H. Non-invasive ventilation in acute respiratory failure in children. Pediatr Rep 2012; 4:e16. doi: 10.4081/pr.2012.e16.

15. Javouhey E, Barats A, Richard N, Stamm D, Floret D. Noninvasive ventilation as primary ventilatory support for infants with severe bronchiolitis. Intensive Care Med 2008; 34:1608-14. doi: 10.1007/s00134-008-1150-4.

16. Mayordomo-Colunga J, Medina A, Rey C, Concha A, Menéndez S, Arcos ML, et al. Non-invasive ventilation in pediatric status asthmaticus: A prospective observational study. Pediatr Pulmonol 2011; 46:949-55. doi: 10.1002/ppul.21466.

17. Mayordomo-Colunga J, Medina A, Rey C, Concha A, Menéndez S, Los $A \operatorname{rcos} \mathrm{M}$, et al. Non invasive ventilation after extubation in paediatric patients: A preliminary study. BMC Pediatr 2010; 10:29. doi: 10.1186/1471-2431-10-29.

18. Fernández Lafever S, Toledo B, Leiva M, Padrón M, Balseiro M, Carrillo A, et al. Non-invasive mechanical ventilation after heart surgery in children. BMC Pulm Med 2016; 16:167. doi: 10.1186/ s12890-016-0334-x.

19. Pancera CF, Hayashi M, Fregnani JH, Negri EM, Deheinzelin D, de Camargo B. Noninvasive ventilation in immunocompromised pediatric patients: Eight years of experience in a pediatric oncology intensive care unit. J Pediatr Hematol Oncol 2008; 30:533-8. doi: 10.1097/MPH.0b013e3181754198.

20. Pediatric Acute Lung Injury Consensus Conference Group. Pediatric acute respiratory distress syndrome: Consensus recommendations from the Pediatric Acute Lung Injury Consensus Conference. Pediatr Crit Care Med 2015; 16:428-39. doi: 10.1097/ PCC.0000000000000350.

21. Fraticelli AT, Lellouche F, L'her E, Taillé S, Mancebo J, Brochard L. Physiological effects of different interfaces during noninvasive ventilation for acute respiratory failure. Crit Care Med 2009; 37:939-45. doi: 10.1097/CCM.0b013e31819b575f.

22. Pravinkumar SE. A face that matters in distress: Interface selection for acute noninvasive ventilation. Crit Care Med 2009; 37:344-6. doi: 10.1097/CCM.0b013e318193050f.

23. Argent AC. Noninvasive ventilator support: The details lies in the interface. Respir Care 2015; 60:1708-10. doi: 10.4187/ respcare.04492.

24. Chidini G, Calderini E, Cesana BM, Gandini C, Prandi E, Pelosi P. Noninvasive continuous positive airway pressure in acute respiratory failure: Helmet versus facial mask. Pediatrics 2010; 126;e330-6. doi: 10.1542/peds.2009-3357.

25. British Thoracic Society Standards of Care Committee. Noninvasive ventilation in acute respiratory failure. Thorax 2002; 57:192-211. doi: 10.1136/thorax.57.3.192.

26. Mayordomo-Colunga J, Pons M, López Y, José Solana M, Rey C, Martinez-Camblor P, et al. Predicting non-invasive ventilation failure in children from the $\mathrm{SpO} 2 / \mathrm{FiO} 2(\mathrm{SF})$ ratio. Intensive Care Med 2013; 39:1095-103. doi: 10.1007/s00134-013-2880-5. 
27. James CS, Hallewell CP, James DP, Wade A, Mok QQ. Predicting the success of non-invasive ventilation in preventing intubation and re-intubation in the paediatric intensive care unit. Intensive Care Med 2011; 37:1994-2001. doi: 10.1007/s 00134-011-2386-y.

28. Bernet V, Hug MI, Frey B. Predictive factors for the success of noninvasive mask ventilation in infants and children with acute respiratory failure. Pediatr Crit Care Med 2005; 6:660-4. doi: 10.1097/01.PCC.0000170612.16938.F6.

29. Mayordomo-Colunga J, Medina A, Rey C, Díaz JJ, Concha A, Los Arcos M, et al. Predictive factors of non invasive ventilation failure in critically ill children: A prospective epidemiological study. Intensive Care Med 2009; 35:527-36. doi: 10.1007/s00 134-008-1346-7.

30. Muñoz-Bonet JI, Flor-Macián EM, Brines J, Roselló-Millet PM, Cruz Llopis M, López-Prats JL, et al. Predictive factors for the outcome of noninvasive ventilation in pediatric acute respiratory failure. Pediatr Crit Care Med 2010; 11:675-80. doi: 10.10 97/pcc.0b013e3181d8e303.

31. Lee JH, Rehder KJ, Williford L, Cheifetz IM, Turner DA. Use of high flow nasal cannula in critically ill infants, children, and adults: A critical review of the literature. Intensive Care Med 2013; 39:247-57. doi: 10.1007/s00134-012-2743-5.

32. Frat JP, Coudroy R, Marjanovic N, Thille AW. High-flow nasal oxygen therapy and noninvasive ventilation in the management of acute hypoxemic respiratory failure. Ann Transl Med 2017; 5:297. doi: 10.21037/atm.2017.06.52.

33. Hegde S, Prodhan P. Serious air leak syndrome complicating high-flow nasal cannula therapy: A report of 3 cases. Pediatrics 2013; 131:e939-44. doi: 10.1542/peds.2011-3767.

34. Long E, Babl FE, Duke T. Is there a role for humidified heated high-flow nasal cannula therapy in paediatric emergency departments? Emerg Med J 2016; 33:386-9. doi: 10.1136/ emermed-2015-204914.

35. Dysart K, Miller TL, Wolfson MR, Shaffer TH. Research in high flow therapy: Mechanisms of action. Respir Med 2009; 103:1400-5. doi: 10.1016/j.rmed.2009.04.007.

36. Sivieri EM, Gerdes JS, Abbasi S. Effect of HFNC flow rate, cannula size, and nares diameter on generated airway pressures: An in vitro study. Pediatr Pulmonol 2013; 48:506-14. doi: 10.1002/ ppul.22636.

37. Sreenan C, Lemke RP, Hudson-Mason A, Osiovich H. Highflow nasal cannulae in the management of apnea of prematurity: A comparison with conventional nasal continuous positive airway pressure. Pediatrics 2001; 107:1081-3. doi: 10.1542/peds. 107.5.1081.

38. Mikalsen IB, Davis P, Øymar K. High flow nasal cannula in children: A literature review. Scand J Trauma Resusc Emerg Med 2016; 24:93. doi: 10.1186/s13049-016-0278-4.

39. Milési C, Baleine J, Matecki S, Durand S, Combes C, Novais AR, et al. Is treatment with a high flow nasal cannula effective in acute viral bronchiolitis? A physiologic study. Intensive Care Med 2013; 39:1088-94. doi: 10.1007/s00134-013-2879-y.

40. Spentzas T, Minarik M, Patters AB, Vinson B, Stidham G. Children with respiratory distress treated with high-flow nasal cannula. J Intensive Care Med 2009; 24:323-8. doi: 10.1177/088506660 9340622.

41. Frat JP, Thille AW, Mercat A, Girault C, Ragot S, Perbet S, et al. High-flow oxygen through nasal cannula in acute hypoxemic respiratory failure. N Eng J Med 2015; 372:2185-6. doi: 10.1056/ NEJMoa1503326.

42. Roca O, de Acilu MG, Caralt B, Sacanell J, Masclans JR; ICU collaborators. Humidified high flow nasal cannula supportive therapy improves outcomes in lung transplant recipients readmitted to the intensive care unit because of acute respiratory failure. Transplantation 2015; 99:1092-8. doi: 10.1097/TP. 0000000000000460.
43. Kawaguchi A, Yasui Y, deCaen A, Garros D. The clinical impact of heated humidified high-flow nasal cannula on pediatric respiratory distress. Pediatr Crit Care Med 2017; 18:112-19. doi: 10.10 97/PCC.0000000000000985.

44. Beggs S, Wong ZH, Kaul S, Ogden KJ, Walters JA. High-flow nasal cannula therapy for infants with bronchiolitis. Cochrane Database Syst Rev 2014; 1:CD009609. doi: 10.1002/14651858. CD009609.pub2.

45. Franklin D, Babl FE, Schlapbach LJ, Oakley E, Craig S, Neutze J, et al. A randomized trial of high-flow oxygen therapy in infants with bronchiolitis. N Engl J Med 2018; 378:1121-31. doi: 10.10 56/NEJMoa1714855

46. Schlapbach LJ, Schaefer J, Brady AM, Mayfield S, Schibler A. High-flow nasal cannula (HFNC) support in interhospital transport of critically ill children. Intensive Care Med 2014; 40:592-9. doi: 10.1007/s00134-014-3226-7.

47. Schibler A, Pham TM, Dunster KR, Foster K, Barlow A, Gibbons K, et al. Reduced intubation rates for infants after introduction of high-flow nasal prong oxygen delivery. Intensive Care Med 2011; 37:847-52. doi: 10.1007/s00134-011-2177-5.

48. McKiernan C, Chua LC, Visintainer PF, Allen H. High flow nasal cannulae therapy in infants with bronchiolitis. J Pediatr 2010; 156:634-8. doi: 10.1016/j.jpeds.2009.10.039.

49. Hernández G, Vaquero C, Colinas L, Cuena R, González P, Canabal A, et al. Effect of postextubation high-flow nasal cannula vs noninvasive ventilation on reintubation and postextubation respiratory failure in high-risk patients: A randomized clinical trial. JAMA 2016; 316:1565-74. doi: 10.1001/jama.2016.14194.

50. Hernández G, Vaquero C, González P, Subira C, Frutos-Vivar F, Rialp G, et al. Effect of postextubation high-flow nasal cannula vs conventional oxygen therapy on reintubation in low-risk patients: A randomized clinical trial. JAMA 2016; 315:1354-61. doi: 10.1001/jama.2016.2711.

51. Pedersen MB, Vahlkvist S. Comparison of CPAP and HFNC in management of bronchiolitis in infants and young children. Children (Basel) 2017; 4:E28. doi: 10.3390/children4040028.

52. Milési C, Essouri S, Pouyau R, Liet JM, Afanetti M, Portefaix A, et al. High flow nasal cannula (HFNC) versus nasal continuous positive airway pressure (nCPAP) for the initial respiratory management of acute viral bronchiolitis in young infants: A multicenter randomized controlled trial (TRAMONTANE study). Intensive Care Med 2017; 43:209-16. doi: 10.1007/s001 34-016-4617-8.

53. Roca O, Riera J, Torres F, Masclans JR. High-flow oxygen therapy in acute respiratory failure. Respir Care 2010; 55:408-13.

54. Kubicka ZJ, Limauro J, Darnall RA. Heated, humidified highflow nasal cannula therapy: Yet another way to deliver continuous positive airway pressure? Pediatrics 2008; 121:82-8. doi: 10.1542/ peds.2007-0957.

55. Oto A, Erdoğan S, Bosnnak M. Oxygen therapy via high flow nasal cannula in pediatric intensive care unit. Turk J Pediatr 2016; 58:377-82. doi: 10.24953/turkjped.2016.04.005.

56. Roca O, Messika J, Caralt B, García-de-Acilu M, Sztrymf B, Ricard JD, et al. Predicting success of high-flow nasal cannula in pneumonia patients with hypoxemic respiratory failure: The utility of the ROX index. J Crit Care 2016; 35:200-5. doi: 10.10 16/j.jcrc.2016.05.022

57. Sztrymf B, Messika J, Bertrand F, Hurel D, Leon R, Dreyfuss D, et al. Beneficial effects of humidified high flow nasal oxygen in critical care patients: A prospective pilot study. Intensive Care Med 2011; 37:1780-6. doi: 10.1007/s00134-011-2354-6.

58. Rello J, Pérez M, Roca O, Poulakou G, Souto J, Laborda C, et al. High-flow nasal therapy in adults with severe acute respiratory infection: A cohort study in patients with 2009 influenza A/H1N1v. J Crit Care 2012; 27:434-9. doi: 10.1016/j.jcrc.2012.04.006. 
59. Abboud PA, Roth PJ, Skiles CL, Stolfi A, Rowin ME. Predictors of failure in infants with viral bronchiolitis treated with highflow, high-humidity nasal cannula therapy*. Pediatr Crit Care Med 2012; 13:e343-9. doi: 10.1097/PCC.0b013e31825b546f.

60. de Klerk A. Humidified high-flow nasal cannula: Is it the new and improved CPAP? Adv Neonatal Care 2008; 8:98-106. doi: 10.1097/01.ANC.0000317258.53330.18.
61. Pilar J, Modesto I Alapont V, Lopez-Femandez YM, LopezMacias O, Garcia-Urabayen D, Amores-Hernandez I. High-flow nasal cannula therapy versus non-invasive ventilation in children with severe acute asthma exacerbation: An observational cohort study. Med Intensiva 2017; 41:418-24. doi: 10.1016/j.medine.20 17.01.001 